Review

\title{
Impact and Mitigation of Nutrient Pollution and Overland Water Flow Change on the Florida Everglades, USA
}

\author{
Kristin Schade-Poole and Gregory Möller* \\ Environmental Science Program, College of Agricultural and Life Sciences, University of Idaho, Moscow, \\ ID 83844, USA; scha3747@vandals.uidaho.edu \\ * Correspondance: gmoller@uidaho.edu; Tel.: +1-208-885-0441 \\ Academic Editor: Vincenzo Torretta \\ Received: 18 July 2016; Accepted: 7 September 2016; Published: 14 September 2016
}

\begin{abstract}
A subtropical watershed and wetland covering nearly $47,000 \mathrm{~km}^{2}$ in the southeastern United States, the Florida Everglades is a degraded, human-dominated environment. As a unique and important ecosystem, the Everglades provide a variety of important environmental services for society and nature. Over the past century and a half, anthropogenic actions have severely impacted the Everglades by disrupting the natural water flow and causing water pollution. As a result, the native flora and fauna have been displaced, important habitats have been lost, invasive species have become prevalent, and water contaminant concentrations have increased. Accelerating efforts are being made towards preserving the Everglades ecosystem by restoring water flow and improving water quality. To explore this complex and important aquatic ecosystem, we critically review the relevant environmental history, major terrestrial and aquatic characteristics and dynamics, engineered changes to water flow, major sources and impacts of nutrient pollution, trends in system response to pollution and mitigation actions, and recent regulatory efforts driving restoration.
\end{abstract}

Keywords: Everglades; Everglades Agricultural Area; phosphorus; nutrient pollution; wetland; restoration; best management practices; stormwater treatment; phosphorus reduction

\section{Introduction}

The Florida Everglades are one of the major wetlands of the world. This regional subtropical watershed and wetland covering nearly $47,000 \mathrm{~km}^{2}$ at the most southeastern point of the continental United States has been experiencing significant land use and water quality changes over the century and a half that have led to a decline in overall ecosystem quality. At present it is a disconnected and compartmentalized, human-dominated ecosystem. Agricultural activity, as well as urban, ex-urban and rural development, invasive species, and early flood control projects have all contributed to this decline. In response, the Everglades region is the target of the largest intergovernmental environmental restoration action in the world, enacted in 2000 by the U.S. Federal Government in cooperation with the State of Florida, numerous governmental agencies, and stakeholder groups. Called the Comprehensive Everglades Restoration Plan (CERP), the action is expected to require decades of effort and billions of dollars in expense [1].

The Florida Everglades are at present very complex in their intertwined natural and human systems. Decades of restoration activities have targeted rebalancing this ecosystem towards natural processes, however integrated human activity such as a productive agricultural economy, nearby urban and suburban development, provision of drinking water, and an active coastal fishery challenge these restoration efforts. The multi-tiered complexity of this human dominated ecosystem makes it difficult for those outside the local and active management of the system to fully comprehend the nature of 
this extraordinary environmental system and complex restoration actions. In this review, we explore the historical background and current human engineered situation of this remarkable ecosystem, highlighting the specific future challenges in its restoration. This exploration critically summarizes major published works and reviews geographical imagery illustrating the scope of the change dynamic, underscoring successes or failures of past management actions. Key foci of the analysis are the impact of agriculture and the built environment within the watershed in the form of nutrient pollution and related engineered changes to overland water flow.

The State of Florida's narrative water quality standard for nutrients, augmented by recent numerical nutrient concentration standards, reads "In no case shall nutrient concentrations of a body of water be altered so as to cause an imbalance in natural populations of aquatic flora or fauna" [2]. The early impacts of CERP and other recent mitigation actions have been positive with significant reductions in pollution and a reversal in the trend of several negative indicators. However, the magnitude of ecosystem change from anthropogenic impact is such that considerable effort remains to achieve a sustainable balance in this human dominated watershed and wetland. Creative solutions co-synthesizing sustainable development, engineering innovation, biomimicry, best management practices, resource conservation and new science are being driven by regulatory pressure, resource limitations, climate change impacts, behavioral and societal change, as well as the actions of concerned citizens and non-governmental organizations such as the Everglades Foundation and the Everglades Coalition, an alliance of 56 local, state, and national conservation organizations working towards restoration. Complicating the advance of restoration efforts is a web of political, economic, social, and technical dynamics that can sum to maintain the largely negative status quo. Although the complexity, scale and the scope of the challenge is daunting, we conclude these efforts are providing hope for preserving the unique ecosystem of the Florida Everglades.

\section{The Everglades}

The Everglades are a region of wetlands located in the southern tip of the Florida peninsula and are the largest within the United States [3]. This subtropical wetland historically covered more than $10,000 \mathrm{~km}^{2}$-approximately $160 \mathrm{~km}$ long and 65 to $80 \mathrm{~km}$ wide-as it extended from the southern end of Lake Okeechobee to Florida Bay [4]. With a maximum elevation of 3.6 to $4.3 \mathrm{~m}$ above sea level near Lake Okeechobee, the Everglades maintains an imperceptible slope falling to the south [5]. The subtropical climate of south Florida consists of a wet season from May to October in which 75\% of the annual precipitation occurs. The amount of rainfall fluctuates year to year varying from 86 to $224 \mathrm{~cm}$ annually [6]. Historically, during the rainy season, Lake Okeechobee would overflow its southern banks and a continuous sheet of water would move slowly south over the relatively flat topography of the Everglades [1].

The Everglades are a unique wetland because rainfall is the predominant source from which water flow is derived. Prior to the late 1800s, water flow of the Everglades hydrologic system was composed of $81 \%$ from precipitation, $8 \%$ from lake overflow, $10 \%$ from marginal runoff, and $1 \%$ from groundwater [7]. In addition to surface flow, infiltrated water is important to groundwater flow and supply. The Biscayne Aquifer lies beneath the Everglades and provides water to major population areas [7]. This aquifer is composed of highly permeable limestone and less permeable sandstone, which allows for water exchange between surface and ground water as it flows easily through the rock [5]. As a result, the contamination of surface water can result in contamination of drinking water resources, which can have serious negative impacts on the environment and nearby rural, suburban, and urban communities.

Because of the low topographic relief, hydrologic flow of water has played a significant role in shaping the ecosystem of the Everglades. The dominant bedrock throughout the area is karstic limestone [8]. This karst topography is formed as the result of dissolution of limestone by weakly acidic groundwater and rainfall. As water enters into cracks and fractures, it creates sinkholes, caves, and complex drainage patterns in the bedrock as it dissolves the limestone [5]. Over thousands of years, 
this and the alternating rising and falling of sea levels have caused organic material to accumulate within sinkholes. This organic material is known as peat and is made up of fine sediment and decaying plant material [5]. The peat soils range in thickness from $4 \mathrm{~m}$ in the north to less than $20 \mathrm{~cm}$ in parts of Everglades National Park [3]. Another commonly found sediment deposit along with peat is marl, a calcitic soil which is deposited during drier times. Peat deposits continue to accumulate and build up higher landforms which lead to the establishment of plant communities and creation of tree islands [5]. High points of land formed by elongated ridges and tree islands, and low points of sloughs through which water flows slowly and continuously create a corrugated landscape pattern (Figure 1). These landforms maintain a parallel orientation, linear with the direction of water flow $[9,10]$.

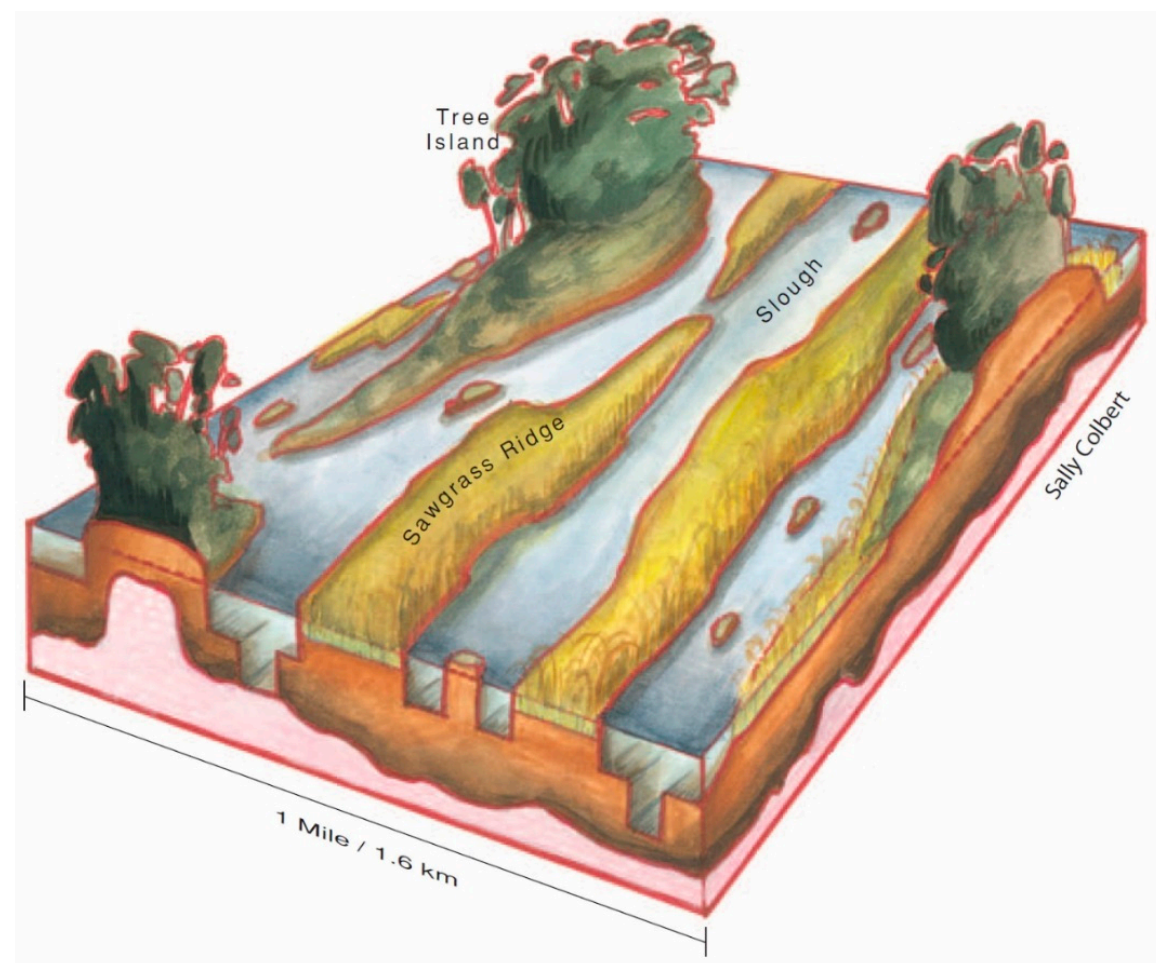

Figure 1. Diagram showing ridge and slough pattern of the Everglades landscape. Source: Modified from McVoy et al. (p. 67) [11].

The Everglades is a highly diverse and dynamic ecosystem made up of many different types of habitats: sawgrass marshes, wet prairies, sloughs, small tree islands, and mangrove estuaries [4]. A brief description of the habitats follows.

The most dominant vegetation found in the Everglades is sawgrass (Cladium jamaicense). This dominance has led to the characterization of the northern Everglades region as a sawgrass prairie. Sawgrass grows $2-3 \mathrm{~m}$ tall in moderate levels of water, in both sparse and dense vegetation communities. Sawgrass marshes prefer flooded areas of $10-20 \mathrm{~cm}$ of water but when periods of drought occur, sawgrass is able to survive in dry conditions. Sawgrass can grow as a pure stand, but more commonly grows mixed with other plants. Some types of plants that grow with sawgrass are bulltongue (Sagittaria lancifolia), maidencane (Panicum hemitomon), pickerelweed (Pontederia cordata), spikerush (Eleocharis cellulose), or cattail (Typha domingensis) [3,6,12-15].

Wet prairies, also known as flats, are transition areas between sawgrass and sloughs, thus water depth is deeper than sawgrass marshes but shallower than sloughs. Low stature and emergent plants are found within these areas. There are three main species compositions that form their respective namesake types of flats: Rhynchospora spp., Panicum hemitomon, and Eleocharis cellulosa. Although these areas are covered in water for 6-10 months of the year, they dry out annually which allows for seed germination $[3,16]$. 
Sloughs are drainage channel areas which are inundated with water most of the year. Water within these low-lying areas is deep and continually flowing. Vegetation that commonly grows in these open water habitats are floating aquatic plants such as white waterlily (Nymphaea odorata), floating hearts (Nymphoides aquatic), bladderworts (Utricularia spp.), spatterdock (Nuphar lutea), and water hyssop (Bacopa caroliniana) [3,14-18].

Tree islands make up less than $5 \%$ of the habitat in the Everglades. These habitats are found on small, round or tear-drop shaped islands that are around $100 \mathrm{~m}^{2}$ in size. The accumulation of peat creates areas of higher elevation that protect tree islands from flooding and are only inundated with water 2-6 months of the year. Different types of woody shrub and tree growth occur such as red maple (Acer rubrum), red bay (Persea borbonia), pond apple (Annona glabra), live oak (Quercus virginiana), Carolina willow (Salix caroliniana), wax myrtle (Myrica cerifera), swamp bay (Magnolia virginiana), buttonbush (Cephalanthus occidentalis), coco-plum (Crysobalanus icaco), cabbage palmetto (Sabal palmetto), gumbo limbo (Bursera simaruba), and hackberry (Celtis laevigata) [3,6,13,16,17,19].

As the water flowing from the Everglades empties into the Florida Bay, the freshwater and seawater mix forming estuaries of brackish water. Along the coast of Florida Bay are forests of mangroves. These forests consist of black mangroves (Avicennia germinans), white mangroves (Laguncularia racemosa), and the most dominant type-red mangroves (Rhizophora mangle). Mangrove forests are of great significance, as they are one of the most productive aquatic ecosystems $[20,21]$. They protect coastal shores from erosion and storms, and they provide nurseries for many fish species. Mangroves are also very important to water quality through nutrient cycling and reducing pollution through filtering [22].

These mosaics of habitats found in the Everglades support many different species of plants, birds, reptiles, amphibians, mammals, and fish. Wetlands are one of the most productive ecosystems and maintain biologically diverse communities. The Everglades ecosystem supports over 40 endangered and threatened species of plants and animals, such as the Florida panther (Puma concolor coryi), West Indian manatee (Trichechus manatus), America alligator (Alligator mississippiensis), red-cockaded woodpecker (Leuconotopicus borealis), piping plover (Charadrius melodus), wood stork (Mycteria americana), green turtle (Chelonia mydas), Atlantic ridley turtle (Lepidochelys kempii), leatherback turtle (Dermochelys coriacea), and loggerhead turtle (Caretta caretta) to name only a few [4,23]. These animals depend on the Everglades for food, water, shelter, breeding, and migration. Many plants and animals are being displaced from their native habitats due to habitat loss and degradation caused by expanding urbanization, drainage of wetlands, the altering of natural overland water flow, and increased water pollution. The Everglades have seen a $90 \%$ decline in the abundance of wading birds, alone [24]. In addition to the displacement of native species as a result of habitat loss, native species are also threatened by the introduction of non-native, exotic, and invasive species. Non-indigenous species can outcompete native species for required resources such as sunlight, water, and nutrients. An example of this is the invasive, non-native Burmese python (Python bivittatus); these top tier predators can impact vulnerable prey in the food chain including protected or endangered species. The introduction of non-native species also threatens the integrity of the ecosystem by altering the natural ecosystem structure $[25,26]$.

Not only do wetland habitats have significant importance to wildlife and a healthy environment but they also provide important societal services. Wetland areas, such as the Everglades, are essential for flood control by acting as a buffer during times of flooding. The soil and vegetation act as a sponge by absorbing excess water flow and releasing it slowly. The vegetation growth also reduces shoreline erosion and protects soil from water flow [27]. Wetlands also improve water quality through their natural filtering properties. They reduce suspended solids, absorb excess nutrients, and remove pollutants through multiple physical, biological, and geochemical mechanisms. The Everglades natural water purification system is important for the health of all who are dependent on this water source [27]. The Florida economy benefits from the Everglades through tourism, fishing, canoeing, bird watching, and other recreational activities within preserves and state and national parks. Both local residents and visitors find great aesthetic value in the beauty of the Everglades ecosystem [28]. 


\section{Lake Okeechobee}

Lake Okeechobee, whose name means "big water" in the regional Seminole Indian language, is a dominant aquatic resource in the watershed and wetlands of the Everglades. After Lake Michigan, it is the second largest freshwater lake in the contiguous United States. A shallow, eutrophic lake averaging about $3 \mathrm{~m}$ deep, Lake Okeechobee covers about $1800 \mathrm{~km}^{2}$ of southern Florida. Before the installation of channels, dikes, and levees for flood control from the mid-19th to the mid-20th Century, the southern expanse of the Lake transformed into a vast sheet-flow marshland connected to the Everglades wetlands. The two largest surface water inputs into Lake Okeechobee are the Kissimmee River Basin to the North, and the small Fisheating Creek watershed to the east. The Kissimmee River Basin extends from the City of Orlando southward, and is comprised of a chain of more than two dozen lakes incorporating the $85 \mathrm{~km}^{2}$ Kissimmee Chain of Lakes wildlife management area, marshlands, and the Kissimmee River. Agricultural activity accounts for $45 \%$ of land use in the Kissimmee River Basin and $70 \%$ in the Fisheating Creek watershed. More than a quarter of the Florida citrus production occurs on over $900 \mathrm{~km}^{2}$ within these basins, and the region has about a half-million head of beef and dairy cattle in animal agriculture operations. Nutrient release and runoff from agricultural fertilizers and land application of animal manure into the contiguous aquatic ecosystem, coupled with urban/suburban stormwater nutrients, are primary vectors of nutrient loading in Lake Okeechobee and the Everglades watershed [29].

Beyond its current considerable value as a regional resource for agricultural irrigation, community drinking water and aquatic wildlife habitat, Lake Okeechobee is a critical component of the Everglades hydrologic system. Lake Okeechobee has been characterized by three major stressors: (1) high loading of phosphorus from agricultural and urban/suburban development; (2) dikes and channels that disconnect water levels from the natural regional water flow; and (3) non-native plant invasion [30]. Water flow into Lake Okeechobee is comprised of about $50 \%$ rainfall and $25 \%$ Kissimmee River, with the remaining $25 \%$ from groundwater seepage and tributary inflows, including that of Fisheating Creek [31].

\section{Florida Bay}

To a large extent, the southern receiving waters of the Everglades is Florida Bay, a 3-m-deep lagoon extending from the southern Florida mainland to the Florida Keys [32]. The majority of Florida Bay is contained within the Everglades National Park. The hypersaline estuary is impacted by the engineered reduction of freshwater flows, the delivery of nutrient load, and a broad range of chemical contamination, leading to a change in species distribution and abundances and degrading this marine environment [32]. The occurrence of periodic seagrass die-offs are not uncommon and contributes to the high turbidity of these waters, although there is limited understanding of what causes these die-offs [33]. Dissolved organic matter and diversion of freshwater away from Florida Bay has been cited as being responsible for a cascade of food web changes leading to higher trophic level vertebrate fauna population decline [34]. Sediment profiles of total phosphorus in the southern Everglades and in Florida Bay indicate that in the past hundred years, anthropogenic inputs from freshwater runoff have resulted in a 2 to 3-fold increase in sediment phosphorus [35]. Nutrient loading of phosphorus and nitrogen are a major concern for the coastal waters of Florida Bay. Excess levels of nutrients found in large bays and estuaries often result in eutrophication because of algal growths within these areas [36]. Phosphorus and nitrogen loading require management in eutrophying estuaries in order to reduce the negative impact on water quality, marine life, and the health of the ecosystem [37].

\section{Landscape and Overland Water Flow Change}

\subsection{Development of the Everglades}

Beginning in the mid-1800s, the central targets of water management within the Florida Everglades were flood control, regulation of water flow, and supplying water for a growing regional population. 
As development increased, draining of the native wetlands became the primary focus. Communities and agricultural activities that became prevalent required access to dry land and water. As a result, water which naturally flowed as overland flow became highly managed and regulated by a man-made, engineered system. Figure 2A shows a simulated satellite image of the pre-drainage extent of the Everglades, and Figure 2B shows the modern extent of the Everglades. As can be seen in the images, the Everglades landscape has been significantly altered by anthropogenic development. With the construction of levees, canals, and pumping stations, wetlands were drained to make space for urban development and agriculture. On the southern bank of Lake Okeechobee, a levee was built preventing water from naturally flowing over the bank during the wet seasons and instead, carried water through canals to channel the flow and drain the land just south of the lake [7]. This interruption of the natural overland flow from the lake resulted in the Everglades being reduced to $50 \%$ of its original size [4]. The drained area just south of Lake Okeechobee was found to be rich in organic soil, which led to the expansion of agriculture and development [4]. This $2800 \mathrm{~km}^{2}$ area became known as the Everglades Agriculture Area (EAA). The most common crop cultivated is sugarcane, making up $80 \%$ of the cropland; the remainder of the area planted includes crops of sod, rice, and vegetables [38].
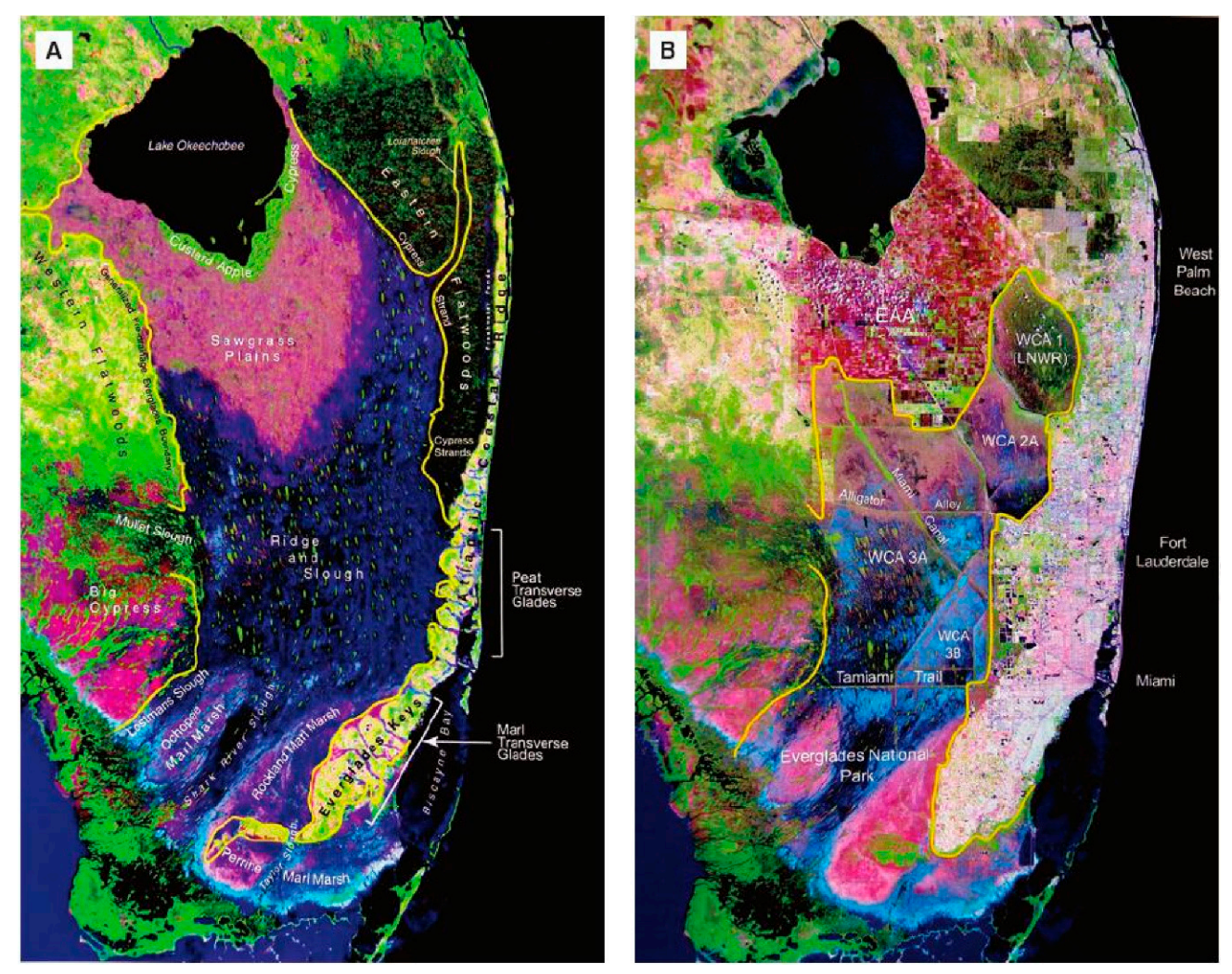

Figure 2. (A) Simulated satellite image of original extent of the Everglades; (B) Modern landscape of the Everglades: Everglades Agricultural Area (EAA), Water Conservation Areas (WCAs), and Everglades National Park. Credit: U.S. Army Corps of Engineers and South Florida Management District [6].

Levees and canals have compartmentalized the Everglades ecosystem into three different Water Conservation Areas (WCA1, WCA2, WCA3), with canals carrying the flow of water downstream instead of as a natural overland sheet flow. These engineered WCAs are meant to act as a buffer between the Everglades Agricultural Area (EAA) and Everglades National Park to protect it from high phosphorus inputs [38]. This compartmentalization of the Everglades ecosystem can be observed in Figure 3. Within these WCAs, water depths and hydroperiods have been altered, severely impacting the ecosystem [1]. This disruption of overland flow has altered much of the Everglades ecosystem creating great challenges for restoration. Alteration of the natural overland flow has changed the 
seasonal spatial extent, water depths, and duration of water in the Everglades. As a result of this altered hydrologic cycle, native vegetation communities are displaced or lost because the environmental factors necessary to support them are no longer present. Additionally, this has led to the displacement of animal communities, especially fish and fowl. Less water leads to less habitat available for wading birds and aquatic life to survive [24]. Changes to water depth and seasonality are also resulting in a loss of the natural landscape complexity of the Everglades. Hydrologic changes are responsible for the loss of the natural ridge and slough patterned landscape and the loss of hundreds of tree island habitats in the central Everglades. Tree islands are important hotspots of biodiversity within the Everglades and are essential for the survival of much of the native flora and fauna of the area $[39,40]$. Over time, these anthropogenic changes have had numerous negative impacts on the environment and environmental services provided by the Everglades habitat. As water is pumped from groundwater, especially during times of drought, saltwater intrusions occur in which saline water moves into aquifers and contaminates drinking water [41]. The Biscayne aquifer located in southeast Florida, which is the primary water supply for southern Florida's populations, has been severely impacted and continues to be threatened by salt water intrusion [42,43]. Additionally, land subsidence is becoming an issue in areas that have been drained, impacting both urban development and agricultural areas [41].

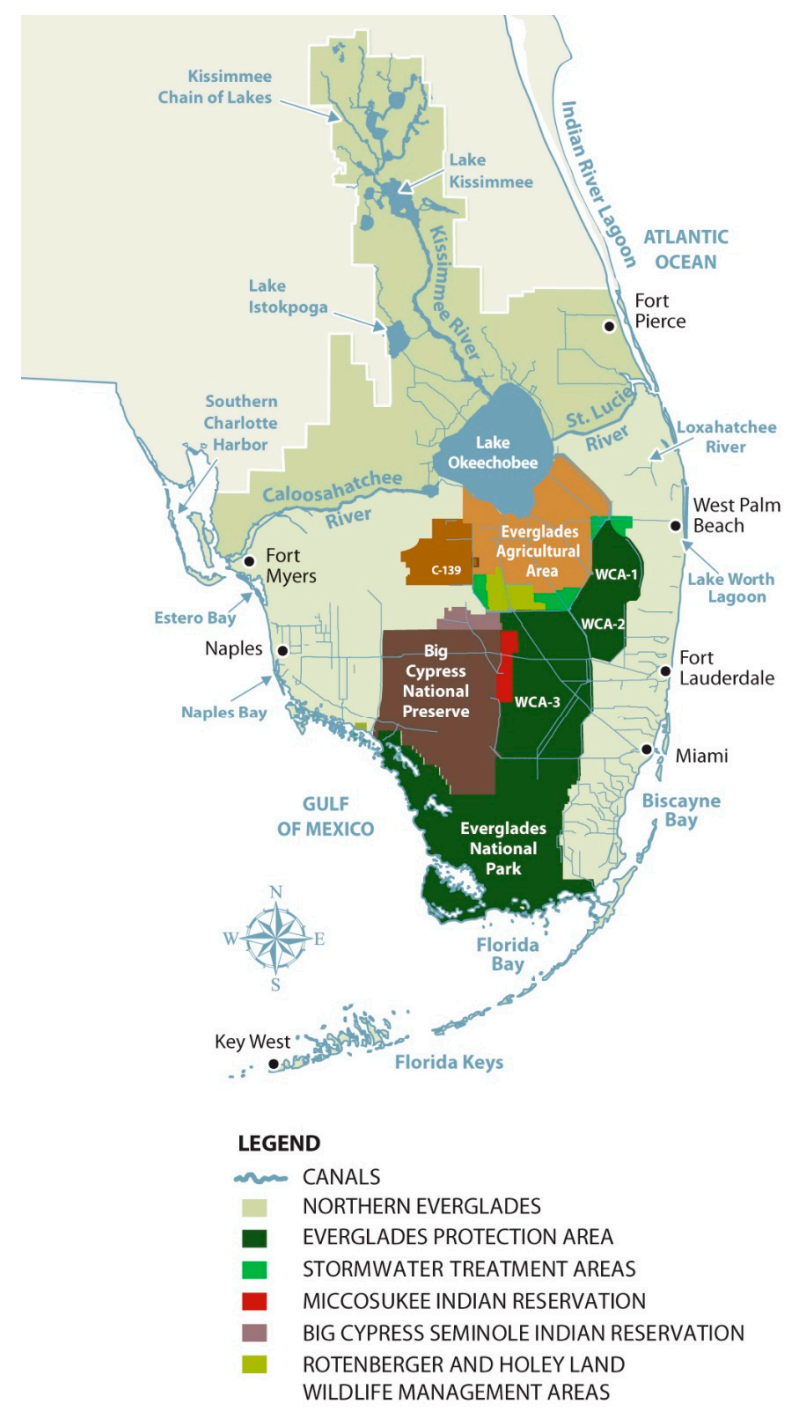

Figure 3. Compartmentalization of the present day managed Everglades ecosystem is broken up with the construction of levees, canals, and water control structures. Credit: South Florida Water Management District [25]. 


\subsection{Water Quality Impacts}

In addition to the negative environmental impact that altering the overland water flow has had on the Florida Everglades, agricultural activities have also led to water quality issues of wetland eutrophication, water contamination, and decreased coastal water-quality [1]. Urban and agricultural activity within the Kissimmee River Basin, the EAA, and the population centers of nearby West Palm Beach, Fort Lauderdale, and Miami has resulted in a number of water quality problems. Urban/suburban stormwater runoff and agricultural runoff from fertilized cropland and manure amended lands have resulted in water pollution within the Everglades. For example, the entire Greater Everglades Ecosystem (which includes the Upper Chain of Lakes Basin and continues south all the way to the coast of Everglades National Park) is estimated to contain 400,000 metric tons of phosphorus, and the soils of the EAA may release approximately 170 metric tons of phosphorus per year over the next century [44]. As water flushes urban and rural built environments and drains agricultural fields, pollution picked up by the runoff is carried into canals which end up being discharged into the WCAs, Everglades National Park, and/or costal estuaries [45,46]. In a 2012 USGS study of anthropogenic nutrient loading into Lake Okeechobee of the Everglades watershed between 2004 and 2008, mean total phosphorus (TP) concentrations ranged from 0.10 to 0.54 milligrams per liter (mg/L), organic nitrogen plus ammonia ranged from 1.27 to $2.96 \mathrm{mg} / \mathrm{L}$, and nitrite plus nitrate ranged from 0.01 to $0.55 \mathrm{mg} / \mathrm{L}$ [31].

A particular concern is the phosphorus from the EAA and urban areas loading the sediment in the $2500 \mathrm{~km}$ of canals in the WCAs. This occurs when phosphorus binds to soil and organic material through a reaction called P-sorption, dominated by iron-aluminum and calcium-magnesium complexes and clay minerals, in addition to humic-fulvic acid phosphorus, and biological or detrital peat incorporated P fractions $[47,48]$. Periodic flooding and extreme weather events such as hurricanes can release light, and sometimes heavy sediment fractions and the stored phosphorus. A 2006 study estimated an Everglades canal with a sediment volume of 6.8 million $\mathrm{m}^{3}$, to contain about 1800 metric tons of phosphorus, which can pose a significant threat to the Everglades water quality [48].

This eutrophying nutrient discharge is contaminating the water that flows through the Everglades and negatively impacts plant, animal, and human life throughout the area. Surface water and sediment have also been found to be contaminated with residual pesticides and herbicides that are used on crops [1]. A 2015 study of agricultural chemicals in the water of the extended Lake Okeechobee and Everglades watersheds periodically detected trace levels $(<0.00015 \mathrm{mg} / \mathrm{L})$ of the herbicides 2,4-D, ametryn, atrazine, bentazon, diuron, metolachlor, metribuzin, along with the insecticide imidacloprid, however all detections were below the threshold of concern for aquatic toxicity [49]. Endosulfan, a persistent, bioaccumulative and toxic organochlorine insecticide and acaricide used in South Florida until its regulatory phase out at the end of 2014, is ubiquitous in the South Florida aquatic ecosystem and presents potential risk to freshwater organisms of the Everglades ecosystem [50,51].

Mercury has been characterized as a significant problem in the Everglades Protection Area, which is composed of all WCAs and the Everglades National Park [52]. As a result of the use of sulfate soil amendments in the EAA and the global atmospheric deposition of mercury from coal combustion energy production, there are observations of elevated concentrations of mercury in higher trophic level Everglades fish and aquatic birds. Sulfate stimulates the metabolic pathways of sulfate reducing bacteria in sediments, co-metabolizing inorganic mercury into methylmercury, a persistent, bioaccumulative and neuro-toxic compound that impacts the aquatic food chain. A relationship between surface water sulfate and total mercury in fish has identified water sulfate management as a target for mercury risk management in the Everglades Protection Area [53]. Over $4000 \mathrm{~km}^{2}$ are contaminated with mercury and the Everglades has some of the highest observed mercury levels in fish for the U.S. [1,54]. Florida has a human fish consumption advisory for 20 species of freshwater fish and over 60 species of marine fish [54]. The consumption of mercury contaminated fish can pose health risks to animals, especially birds, and humans. 


\subsection{Nutrient Phosphorus and Nitrogen}

Runoff from the EAA contains elevated levels of nutrients, total suspended solids, biological oxygen demand, pesticides, and bacteria [4]. The Florida Everglades ecosystem is one that is adapted to low, oligotrophic concentrations of nutrients; native plants (including algae) and animals are adapted to survive in nutrient poor-habitats. The exception to this are tree islands habitats, as well as vegetation around ponds, lakes, and alligator holes [3]. The quality of the water entering the Everglades is influential on marsh ecology and high concentrations of nutrients can have harmful impacts on the ecosystem, wildlife, and society [4]. Because of the natural oligotrophic nutrient conditions that the Everglades are adapted to, the elevated concentration of nutrients has led to eutrophication of wetlands as dense algae growth propagates in nutrient-rich environments [24]. These dense growths of algae are detrimental to the ecosystem as they occur rapidly and lead to hypoxia or low dissolved oxygen availability in the water. This lack of dissolved oxygen causes death of aquatic life [55]. Some algal blooms, such as the so-called blue-green algae cyanobacteria, produce toxins which can pose health risks to humans and marine life that come in contact with it [55]. The Everglades were historically characterized by a phosphorus-limited production of plant biomass and slow decomposition of detrital matter by nutrient controlled microbial consortia. Because of these microbial consortia and its ability to accelerate organic matter decay, decomposition of detrital matter leads to further nutrient release which is a critical biogeochemical trigger in the eutrophic cycle of this aquatic ecosystem [56].

As previously mentioned, one of the nutrients that is a specific problem for the Everglades is phosphorus. Elevated levels of phosphorus have caused a shift in vegetation composition from native sawgrass, to increased growth of cattails [57]. The native sawgrass populations are adapted to live in a low nutrient environment. With increasing phosphorus within the Everglades, plants that favor a more nutrient rich environment such as cattails, are dominating the marsh and slough communities [6]. Excess phosphorus is also causing shifts and die-offs of periphyton [57]. Periphyton are microbial mats made up of microalgae, cyanobacteria, fungi, bacteria, small animals, and detritus. These communities are commonly found floating on plants, sediments, and the surface of water [6]. Periphyton are an important source of food for many fish and invertebrates, and also have an important role in providing the necessary dissolved oxygen required for organisms to survive [58]. In addition to cattail encroaching on non-native areas, the increased level of nutrients in the Everglades are leading to rapid invasion of exotic plants which displace indigenous plants [59].

According to estimates of surface-water within the Everglades, pre-drainage phosphorus concentration ranged from 0.004 to $0.010 \mathrm{mg} / \mathrm{L}$. More recent concentrations of phosphorus in canals carrying water to the Everglades range from 0.100 to $1.0 \mathrm{mg} / \mathrm{L}$ from 1975 to 2005 [24]. These elevated levels of phosphorus concentrations over an extended period of time have led to the accumulation of high levels of legacy phosphorus in the impacted soil, sediment and water. The current loading of phosphorus could take many decades to eliminate from the system [60]. In order to clean up the nutrient pollution found in Florida waters, the Florida Forever Act was passed in 1994 in which governmental authorities implemented the process that developed a standard for the level of TP found entering and within the Everglades system as no more than $0.010 \mathrm{mg} / \mathrm{L}[61,62]$.

Nitrogen $(\mathrm{N})$ levels have had a lesser focus as a polluting nutrient in the Everglades, however it remains a key nutrient and an important dynamic in the biogeochemistry of this aquatic ecosystem [63]. Organic nitrogen forms, active nitrogen fixation, and nitrogen storage in the peat fraction of soils and waterway sediments are dominant elements of the regional nitrogen-cycle [63]. The Everglades nitrogen cycle is complex and less understood than the phosphorus-cycle. This is because of the multitude of nitrogen forms; wetland biogeochemical nitrogen storage and release from plant uptake and detrital decay; surface and meteoric (precipitation) water nitrogen contribution and mobilization; seasonal and diurnal temperature effects; the complex action of nitrifying and denitrifying microbes; as well as the impact of periodic extreme wet weather events. Anthropogenic impacts from nearby agriculture and urban/suburban stormwater runoff areas, including dairies in Okeechobee County in 
the Kissimmee River Basin, are a source of nitrogen pollution, in addition to phosphorus. However, sugarcane production located in the EAA requires only phosphorus fertilizer and little nitrogen due to the high nitrogen mineralization from organic matter found in these soils [64]. A 2016 study reviewing decades of ecosystem level study of the relative importance of nitrogen and phosphorus in fresh water eutrophication concludes: "There is no evidence that eutrophication can be managed by controlling $\mathrm{N}$ inputs. In contrast, multiple lines of evidence at the whole-lake scale of management show that P control works to mitigate eutrophication" [65].

\subsection{Numerical Nutrient Water Quality Standards}

A series of Federal and State of Florida agency actions, in response to judicial pressure under the regulatory mandate of the U.S. Clean Water Act (CWA), have forwarded numerical nutrient water quality standards into the management of the Everglades [66,67]. The historical agency actions and case law involved in the CWA "cooperative federalism" as applied to the Everglades has been explored in detail from two diverse legal viewpoints [68,69]. The driver for these actions were the regulatory insufficiency of the existing narrative standard Rule 6.2-302.530(47)(b) of the Florida Administrative Code (F.A.C.) for active management under section 303(c)(4)(b) of the CWA. New data on the background nutrient levels in un-impacted areas of the Everglades aquatic ecosystem showing TP no effect levels of $0.0085 \mathrm{mg} / \mathrm{L}(0.010 \mathrm{mg} / \mathrm{L}, 95 \%$ confidence level $)$, in addition to mesocosm studies designed to explore nutrient trigger levels for undesirable aquatic plant growth at $0.015 \mathrm{mg} / \mathrm{L} \mathrm{TP}$ limits, yielded guidance on the prospective numerical target standards [70-72].

Finalized in 2016, Rule 62-302.531 F.A.C. formulates total nitrogen, total phosphorus, and chlorophyll numerical standards for freshwater streams, lakes, and springs [73]. For example, minimum TP values of $0.010 \mathrm{mg} / \mathrm{L}$ and TN values of $0.51 \mathrm{mg} / \mathrm{L}$ are promulgated for low color and low alkalinity waters [73]. In F.A.C. 62-302.532, the Florida coastline is classified into estuarine segments which are managed by separate numerical standards. The final rules exempt intermittent waters and man-made or altered canals and channels used for water management, irrigation, or water supply. The rules also exempt waterways characterized as poor habitat and imposes a detailed, and perhaps complex, pathway for listing a waterway as "impaired" [74].

Reflecting on the Everglades and other nutrient challenged aquatic ecosystems, Schwartz et al. 2014 suggest "Generic numeric limits for nitrogen and phosphorus are difficult to establish because their effect in any particular stream or lake depends on how they interact with other local factors that help or hurt plant growth, such as sunlight, substrate, alkalinity, temperature, and water flow" and furthermore, that establishing numeric criteria can be "burdensome" [68]. In sharp contrast, Houck 2014 cites an estimate that the exemptions and definitions articulated in the Rule 62-302.531 F.A.C. standards "exclude most flowing waters in South Florida (3043 miles (4897 km)), tidal creeks (6333 miles (10,191 km)), water management canals (11,497 miles (18,501 km), intermittent streams (8701 miles $(14,002 \mathrm{~km}))$, and other downstream waters". The Houck analysis further suggests the final rule action addresses the requirement for numerical standards but allow them only "as inoperative as possible" due to loopholes, exemptions and overly complex and litigious pathways in practical application [69]. This assessment suggests that the Rule 62-302.531 F.A.C. standards, including numerical TP levels, may satisfy CWA technical and judicial requirements but active application in the regulatory arena to address Everglades restoration management needs will be muted.

\subsection{Everglades Restoration}

Because of the deteriorating conditions of the Everglades, action is needed to prevent further damage. In an effort to overcome some of the water management impacts that have emerged because of anthropogenic development, the Central Everglades Restoration Plan was authorized in 2000 by the U.S. Congress to restore the Everglades ecosystem in south Florida. The goal of CERP, as explained in the Water Resources Development Act [75], is to restore and protect the south Florida ecosystem while also providing for the regions' agricultural and urban water needs and flood protection. The CERP 
is an adaptive management plan that seeks to restore the natural overland water flow patterns in the undeveloped wetlands, and also to improve water quality in order to improve the health of the ecosystem [1]. Figure 4 is a comparison of the historic flow, current flow, and the CERP desired flow. The desired CERP flow would be achieved with the removal of dikes and levees and the construction of storage reservoirs to reduce flow to the Atlantic Ocean and Gulf of Mexico in order to restore a more natural water flow to the Everglades [3]. The removal of canals and levees seeks to restore some of the connectivity and natural overland flow of the Everglades. CERP aims to reduce the rapid discharge of excess water, often with high nutrient and sediment loading, to the Caloosahatchee and St. Lucie estuaries during storm and high-flow events (Figure 4). Additionally, the construction of flow equalization basins (FEBs) and water control structures will assist in controlling water flow through capturing runoff from storm events, storing excess water, and releasing it so as to provide a steady flow of water downstream [76]. In this way, water flow can be monitored and controlled in order to maintain optimal water level for the ecosystem especially during times of storm events and drought.

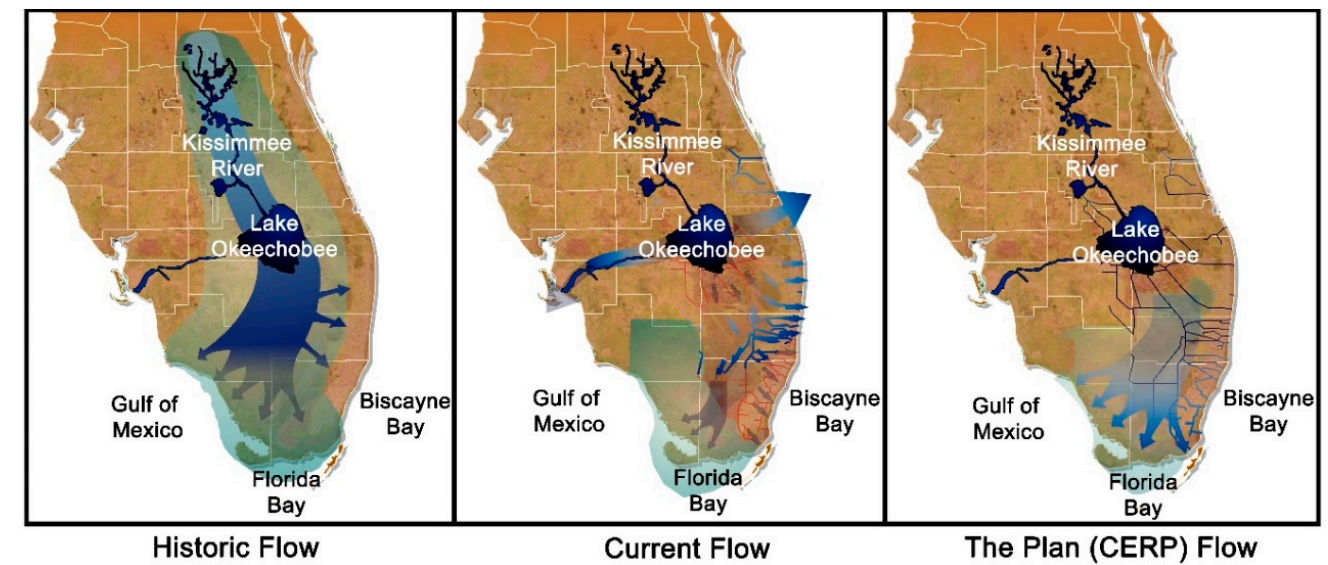

Figure 4. Comparison of historic, current, and planned water flow of the Everglades ecosystem. Credit: U.S. Army Corps of Engineers, Jacksonville District (CERP) [77].

Restoring the overland flow into the Everglades is not the only action important to the CERP. Additionally, efforts to reduce phosphorus levels to the State of Florida accepted level of $0.010 \mathrm{mg} / \mathrm{L}$ are essential to the success of the Everglades restoration. Management and control of phosphorus is done using a two-tier approach [78]. First, phosphorus has been reduced significantly by the implementation of best management practices (BMPs) developed by research within the agricultural areas of the EAA. Secondly, stormwater treatment areas (STAs) are used to remove phosphorus from water discharged from the EAA prior to release into WCAs [4].

\subsection{Best Management Practices}

In order to attain the Florida Everglades phosphorus standard, the use of source controls, or Best Management Practices (BMPs), were applied to agricultural and non-agricultural lands to reduce phosphorus loading [60]. The Everglades Forever Act (EFA) of 1994 put in place a regulatory program to improve water quality and water management, as well as to monitor and reduce the level of phosphorus entering the Everglades ecosystem, eventually to be compliant with the designated limit of $0.010 \mathrm{mg} / \mathrm{L}$ [38]. The EFA's regulatory focus was on keeping water levels high enough to reduce phosphorus mineralization, and reducing phosphorus fertilizer use while maximizing crop production and minimizing negative impacts on the environment [79]. The agricultural focus of this regulatory program required farms to develop and implement a BMP program [38]. BMPs are activities of structural and non-structural nature that are identified as being practical and effective for use to improve the water quality of agricultural and urban discharge [62]. BMPs are area specific and also consider economic and technological factors. Monitoring agricultural discharge of phosphorus 
concentrations is important in assuring that the BMPs are effective for their locations $[38,62]$. Practices that seek to reduce the concentration of phosphorus pollutants or the volume or rate of runoff are a focus area of the BMPs [62]. Specific areas in which BMPs can be optimized involve pesticide management, erosion control, conservation buffers, nutrient and irrigation management, and water resource management [62]. Farmers that have shown that they have effectively implemented these BMP programs receive tax credits and cost-share incentives [38,62].

The use of BMPs within the EAA has resulted in dramatic reductions of phosphorus loading. The reduction of phosphorus entering waterways through the use of BMPs decreases the amount of TP needed to be removed downstream, thus reducing mitigation costs. The implemented regulation for farmers was to reduce phosphorus discharge by $25 \%$ as compared to levels prior to reduction efforts. This goal has been exceeded practically every year. The average reduction of phosphorus loads over the past 20 years has been $56 \%$, and in 2015 the EAA has achieved a TP reduction of $79 \%$ [25].

\subsection{Stormwater Treatment Areas}

The second important approach to managing phosphorus levels is the use of Stormwater Treatment Areas (STAs). The Everglades STAs are the largest constructed wetlands in the world $[80,81]$. While effective at reducing $\mathrm{P}$, an economic analysis of the STAs concludes that operation and management of these facilities are high cost and complex [82].

Even with the use of BMPs, as urban and agricultural runoff leaves the EAA it can still contain phosphorus above target levels ranging from 0.080 to $0.150 \mathrm{mg} / \mathrm{L}$ [78]. In order to be in compliance with target phosphorus levels for input into the Everglades ecosystem, the use of STAs has been implemented. Six STAs that cover a combined area of about $231 \mathrm{~km}^{2}$ have been constructed since 1996 [83]. These constructed wetlands are being used to filter this nutrient-rich runoff to further reduce the nutrient concentrations to be compliant with the regulated level of $0.010 \mathrm{mg} / \mathrm{L}$ that is allowed to enter the Everglades [4].

Prior to water from urban and agricultural runoff entering the WCAs, the water is carried by canals to one of the six STAs found just north of the WCAs as shown in Figure 5 [82]. The STAs are designed to operate so that aquatic plants, with associated microbial and biogeochemical dynamics, are used to remove phosphorus from the water. The runoff is directed to flow through different treatment cells made up of a variety of aquatic plants. These plants remove phosphorus by absorption for use in metabolic processes, and also store it in plant material and cycling plant detritus. The process by which it this occurs is that first, the water flows through treatment cells that contain emergent aquatic vegetation such as cattails. The next treatment cell in which the water passes through contains submerged aquatic vegetation such as hydrilla (Hydrilla verticillata), guppy grass (Najas guadalupensis), and green algae (Chara spp.), by which additional nutrients are removed [82]. Finally, water flows through treatment cells containing floating aquatic vegetation or periphyton mat to further reduce phosphorus levels before being pumped out to flow into the WCAs [58]. STAs are highly managed and monitored systems to assure that the best efficiency is met in improving water quality. Maintenance of the necessary structures for STAs, the filtering vegetation, and water levels within each treatment cell are important for the system to work effectively [83]. By using the FEBs previously mentioned, the amount of water entering the STAs is controlled and monitored so as to maintain ideal water levels for optimal performance of phosphorus reduction [84].

STA's phosphorus reductions are variable within each area, and the amount of phosphorus removed is often dependent on weather, nutrient load, and other factors. From 1996 to 2012, 1560 metric tons of phosphorus were retained, reducing phosphorus loads by $73 \%$ [83]. If inflow into STAs contains $0.120-0.150 \mathrm{mg} / \mathrm{L}$ of phosphorus, the filtration action of the STAs are able to reduce outflow phosphorus concentrations to $0.012-0.018 \mathrm{mg} / \mathrm{L}$ [78]. Overall, STAs have made a significant impact in efforts to reduce phosphorus loading. The 2016 South Florida Environmental Report observes that the STAs have helped to reduce the inflow of phosphorus into the Everglades Protection Area by $83 \%$. Over the past two decades of operation, the STAs have treated about 20 billion $\mathrm{m}^{3}$ of water and 
retained 2012 metric tons of TP. Figure 6 compares the total phosphorus levels of inflow water entering the STAs, and total phosphorus levels of outflow water exiting the STAs. It is clear from the graph that over the years of operation, the STAs have been successful in decreasing outflow phosphorus levels. In 2015 water entering the STAs averaged $0.099 \mathrm{mg} / \mathrm{L}$, and water leaving STAs to the Everglades averaged $0.017 \mathrm{mg} / \mathrm{L}$ [25].

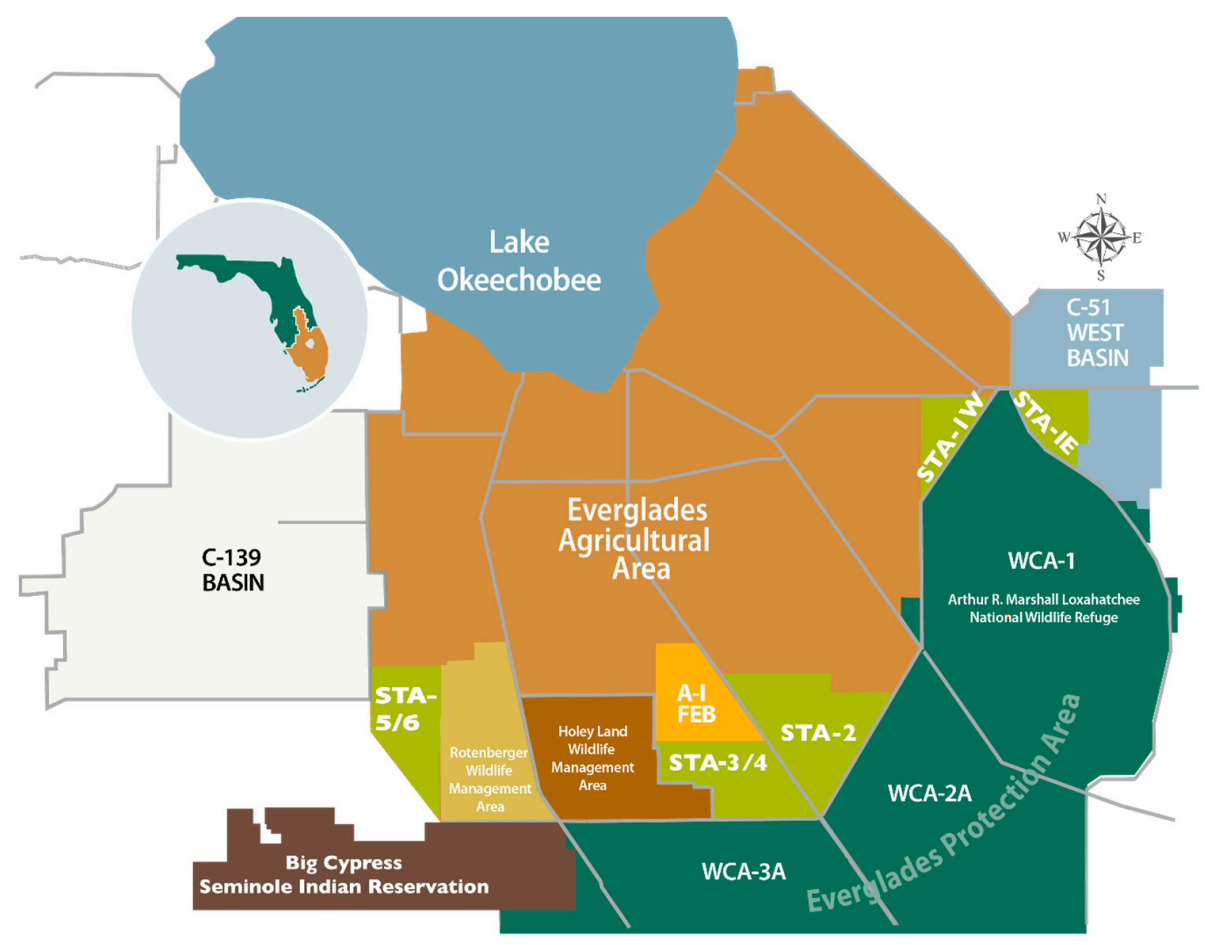

Figure 5. Location of the six Stormwater Treatment Areas (STAs) in light green. Water exits STAs and enters Water Conservation Areas (WCAs). Credit: South Florida Water Management District [84].

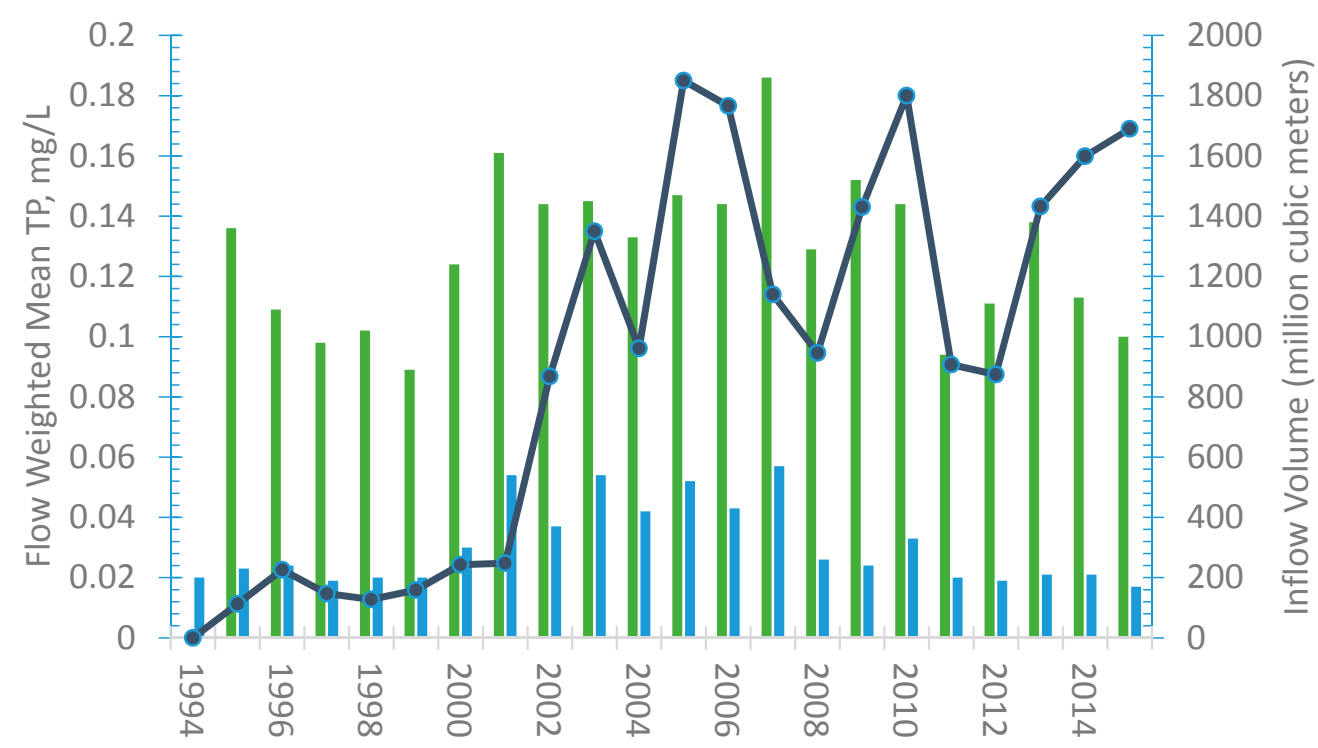

Inflow TP mg/L Outflow TP mg/L $\quad \longrightarrow$ - Inflow Volume MCM

Figure 6. Flow-weighted mean of total phosphorus (TP) in water entering (inflow), and water exiting (outflow) the STAs from water years 1994-2015. Adapted from: South Florida Water Management District [25]. 
While the implementation of upstream phosphorus reduction measures including BMPs, WCAs, and STAs have had a positive impact, Surratt and Aumen, 2014 conclude "the reductions are not yet sufficient to reduce P concentrations to levels protective of Everglades flora and fauna" and "expansion of treatment technology to all potential sources and promotion of sheetflow for water delivery" are needed [57].

In 2014, the Fifth Biennial Review of the Everglades Restoration by the National Research Council identified financial, procedural, policy, and planning challenges as major impediments to maintaining the pace of progress of restoration of the Everglades ecosystem. Climate change driven sea-level rise, compounded with potential temperature and precipitation change and the impacts of invasive species, are increasingly important Everglades management criteria [85].

\section{Conclusions}

Overall, there has been much success and progress in efforts to preserve and protect the Everglades ecosystem through reducing TP loads. However, the amount of legacy phosphorus that persists within the soil, sediments, and water of the system is of continued concern. In a dynamic ecosystem subject to changing environmental factors and disturbances, nutrient concentration can be greatly impacted. During times of drought and decreased rainfall some areas within the STAs dry out, therefore efficiency and performance of STAs are negatively impacted resulting in high TP concentration in the outflow [83]. Other extreme weather events with high winds and heavy rains increase water flow and erosion, which can result in the mixing of phosphorus rich suspended sediment into the water column, thus increasing TP concentration in water flow. Additionally, hurricanes and storms can damage and uproot vegetation communities in STAs and decrease the effectiveness of phosphorus removal with these aquatic plant communities. After extreme weather events, reconstruction, revegetation, rehabilitation, and full recovery of STAs can take 1 to 3 years [83]. As STAs are prone to disturbance and disruption, they will require and depend on adequate funds and societal support in maintenance of these facilities.

Another future concern for the Everglades ecosystem is climate change. With climate change altering temperature, precipitation, and sea-level, the Everglades habitat could be severely impacted. As a coastal area with subtropical climate and low elevation, rising sea-level is of particular concern to the Everglades habitat. Although there is much uncertainty on how quickly and how much the sea-level will rise, it is predicted by 2080 that Florida will see a 0.25 to $0.35-\mathrm{m}$ rise, a significant rise, considering the Everglades maximum elevation of $4.3 \mathrm{~m}$ [86]. In addition to rising sea-levels severely altering the hydrology, salinity, and vegetation of the Everglades ecosystem, TP levels in waterways could increase as a result of hydrograph changes due to increased temperature and seasonal precipitation shifts and change. These changes not only impact the performance of STAs but changing temperatures and precipitation can also modify water level, biogeochemistry, and primary productivity which may impact TP concentration in waterways. With the unknown impact of climate change, ecosystem managers in concert with community members, industry leaders, and State of Florida and Federal governmental agencies must continue to support efforts in reducing phosphorus pollution and increasing overland water flow to restore the Florida Everglades.

A sense of urgency is needed to address the Everglades nutrient pollution and overland water flow challenges. In June 2016, the State of Florida governor issued Executive Order 16-155 declaring a state of emergency in Martin and St. Lucie Counties, located northeast of Lake Okeechobee, following the presence of large-scale harmful algal blooms in local waterways and coastal regions due to the high rainfall driven release of nutrient-laden flows from Lake Okeechobee [87]. In this episode of release of high nutrient waters, the Caloosahatchee Estuary and the St. Lucie Estuary, as well as nearby beaches, waterways, aquatic fauna and recreational areas, were severely impacted. Planned CERP goals aim to redirect much of this lateral estuarine flow by re-establishing overland southward flow.

What is clear is that the status quo in nutrient pollution and water quality is not acceptable in either the social, environmental or economic domains in the Everglades region and other impacted aquatic ecosystems across the globe. New thinking and innovative approaches are clearly needed to 
catalyze cost-effective solutions to these challenges. In one effort to stimulate and accelerate research, development, and breakthroughs in the science and technology of minimizing and mitigating aquatic ecosystem phosphorus, the Everglades Foundation has established "The George Barley Water Prize", the largest clean water science prize offered to date [88]. The goal is to develop new technologies that can, in a cost-effective, efficient way, remove and recycle phosphorus from waterways to aid in reducing nutrient pollution within the Florida Everglades ecosystem and in other nutrient contaminated regions around the globe. Since mined phosphate rock is a non-renewable, and therefore a non-sustainable resource, with $90 \%$ of the mined resources limited to five countries and $80 \%$ of the known reserves found only in Morocco, present and future global food security requires phosphorus recycling $[89,90]$. The Barley Prize seeks to encourage those in the science and engineering community to develop new and innovative ideas to resolve the issue of agricultural pollution and restore the health of the Everglades ecosystem. Over several years, participants will seek to develop, test, and apply phosphorus removal and recovery technology. Entries will be judged based on overall effectiveness, cost-effectiveness, and adaptability, with the winner being awarded the George Barley Prize of US $\$ 10$ million [88].

Marjory Stoneman Douglas, the first to defend the importance of preserving the Everglades, stated in her 1947 book, The Everglades: River of Grass, "There are no other Everglades in the world. They are, they have always been, one of the unique regions of the earth; remote, never wholly known. Nothing is like them" [91]. The Everglades is an important ecosystem to the many different species of plants, birds, reptiles, amphibians, mammals, and fish that are dependent on it for food, water, and shelter. The wetlands of the Everglades are also important to human society by providing drinking water, flood protection, aesthetic value, and economic income. Urban and agricultural development have had many negative environmental impacts by disrupting the natural overland flow and causing water pollution due to high levels of phosphorus concentration. With the combined use of BMPs within the EAA to reduce phosphorus loads from agriculture, and the use of STAs to remove phosphorus concentration further before discharging them into the Everglades, the wetlands water quality is being improved. Additionally, efforts at developing new technologies and innovative approaches that address nutrient contamination in impacted ecosystems are advancing as new knowledge develops. These advances, along with the CERP actions to restore natural overland flow, are providing hope for preserving the unique ecosystem of the Florida Everglades.

Acknowledgments: This work was supported by the USDA National Institute of Food and Agriculture Hatch project IDA01457.

Author Contributions: Kristin Schade-Poole and Gregory Möller conceived and designed the review; Kristin Schade-Poole and Gregory Möller analyzed the data; Kristin Schade-Poole and Gregory Möller wrote the paper.

Conflicts of Interest: The authors declare no conflict of interest. The funding sponsors had no role in the design of the study; in the collection, analyses, or interpretation of data; in the writing of the manuscript, and in the decision to publish the results.

\section{Abbreviations}

The following abbreviations are used in this manuscript:

$\begin{array}{ll}\text { FAC } & \text { Florida Administrative Code } \\ \text { TP } & \text { Total phosphorus } \\ \text { TN } & \text { Total nitrogen } \\ \text { WCA } & \text { Water Conservation Area } \\ \text { EAA } & \text { Everglades Agricultural Area } \\ \text { CERP } & \text { Central Everglades Restoration Plan } \\ \text { FEB } & \text { Flow equalization basins } \\ \text { EFA } & \text { Everglades Forever Act } \\ \text { BMP } & \text { Best management practice } \\ \text { STA } & \text { Stormwater treatment area }\end{array}$




\section{References}

1. Perry, W.B. Everglades restoration and water quality challenges in south Florida. Ecotoxicology 2008, 17, 569-578. [CrossRef] [PubMed]

2. Florida Department of Environmental Protection. Criteria for Surface Water Quality Classification. Available online: http:/ / www.dep.state.fl.us/legal/Rules/shared/62-302/302-Table.pdf (accessed on 17 May 2016).

3. Richardson, C.J. The Everglades: North America's subtropical wetland. Wetl. Ecol. Manag. 2010, 18, 517-542. [CrossRef]

4. Chimney, M.J.; Goforth, G. History and description of the Everglades Nutrient Removal Project, a subtropical constructed wetland in south Florida (USA). Ecol. Eng. 2006, 27, 268-278. [CrossRef]

5. National Park Services. Everglades National Park-Geological Resource Evaluation Report. Available online: https:/ / www.nature.nps.gov/geology/inventory/publications/reports/ever_gre_rpt_view.pdf (accessed on 10 November 2015).

6. Gaiser, E.; Trexler, J.; Wetzel, P. The Florida Everglades. In Wetland Habitats of North America Ecology and Conservation Concerns; Batzer, D., Baldwin, A., Eds.; University of California Press: Berkeley, CA, USA, 2012.

7. Harvey, J.W.; McCormick, P.V. Groundwater's significance to changing hydrology, water chemistry, and biological communities of a floodplain ecosystem, Everglades, South Florida, USA. Hydrogeol. J. 2009, 17, 185-201. [CrossRef]

8. Moller, S. The Everglades National Park—Evolution of the Everglades Peatland. TU-Bergakademie Freiberg. Available online: http://www.geo.tu-freiberg.de/oberseminar/os06_07/stephanie_moeller.pdf (accessed on 2 November 2015).

9. Kotun, K. Everglades National Park 2013 Indicators of Integrity. South Florida Natural Resources Center Status and Trends Report. Available online: http://www.nps.gov/ever/learn/nature/upload/2013_State_ of-Conservation_Indicator_of-Integrity.pdf (accessed on 10 November 2015).

10. Wu, Y.; Wang, N.; Rutchey, K. An analysis of spatial complexity of ridge and slough patterns in the Everglades ecosystem. Ecol. Complex. 2006, 3, 183-192. [CrossRef]

11. McVoy, C.W.; Said, W.P.; Obeysekera, J.; van Arman, J.; Dreschel, T. Landscapes and Hydrology of the Predrainage Everglades; University Press of Florida: Gainsville, FL, USA, 2011; p. 576.

12. Saunders, C.J.; Gao, M.; Lynch, J.A.; Jaffe, R.; Childers, D.L. Using soil profiles of seeds and molecular markers as proxies for sawgrass and wet prairie slough vegetation in Shark Slough, Everglades National Park. Hydrobiologia 2006, 569, 475-492. [CrossRef]

13. Olmsted, I.; Armentano, T.V. Vegetation of Shark Slough, Everglades National Park. South Florida Natural Resources Center Technical Report 97-001. Available online: https://www.nps.gov/ever/learn/nature/ upload/SecureTRSFNRC97-001.pdf (accessed on 25 May 2016).

14. Serna, A.; Richards, J.H.; Troxler, T.G.; Scinto, L.J. Vegetation and soil response to hydrology in a re-created Everglades. Hydrobiologia 2015, 757, 167-183. [CrossRef]

15. U.S. Fish and Wildlife Service. Freshwater Marshes and Wet Prairies. In South Florida Multi-Species Recovery Plan. Available online: https://www.fws.gov/verobeach/MSRPPDFs/FreshMarWetPrairie.pdf (accessed on 25 May 2016).

16. Loveless, C.M. A study of the vegetation in the Florida Everglades. Ecology 1959, 40, 1-9. [CrossRef]

17. Givnish, T.J.; Volin, J.C.; Owen, V.D.; Volin, V.C.; Muss, J.D.; Glaser, P.H. Vegetation differentiation in the patterned landscape of the central Everglades: Importance of local and landscape drivers. Glob. Ecol. Biogeogr. 2008, 17, 384-402. [CrossRef]

18. Larsen, L.; Aumen, N.; Bernhardt, C.; Engel, V.; Givnish, T.; Hagerthey, S.; Harvey, J.; Leonard, L.; McCormick, P.; McVoy, C.; et al. Recent and Historic Drivers of Landscape Changes in the Everglades Ridge, Slough, and Tree Island Mosaic. Environ. Sci. Technol. 2011, 41, 344-381. [CrossRef]

19. Ogden, J.C. Everglades Ridge and Slough Conceptual Ecological Model. Wetlands 2005, 25, 810-820. [CrossRef]

20. Castaneda-Moya, E.; Twilley, R.R.; Rivera-Moya, V.H.; Zhang, K.; Davis, S.E., III; Ross, M. Sediment and Nutrient Deposition Associated with Hurricane Wilma in Mangroves of the Florida Coastal Everglades. Estuar. Coasts 2010, 33, 45-58. [CrossRef] 
21. Castaneda-Moya, E.; Twilley, R.R.; Rivera-Monroy, V.H. Allocation of biomass and net primary productivity of mangrove forests along environmental gradient in the Florida Costal Everglades, USA. For. Ecol. Manag. 2013, 307, 226-241. [CrossRef]

22. Twilley, R.R.; Day, J.W., Jr. The productivity and nutrient cycling of mangrove ecosystems. In Ecosistemas de Manglar en AMERICA Tropical; Yanez-Arancibia, A., Lara-Dominguez, A.L., Eds.; UICN: Gland, Switzerland, 1999; pp. 127-152.

23. National Park Services. Inventory of Threatened and Endangered Species in Everglades National Park. Available online: http://www.nps.gov/ever/learn/nature/techecklist.htm (accessed on 10 November 2015).

24. Sklar, F.H.; Chimney, M.J.; Newman, S.; McCormick, P.; Gawlik, D.; Miao, S.; McVoy, C.; Said, W.; Newman, J.; Coronado, C.; et al. The ecological-societal underpinnings of Everglades restoration. Front. Ecol. Environ. 2005, 3, 161-169.

25. South Florida Water Management District. South Florida Environmental Report-Highlights. Available online: https:/ /issuu.com/southfloridawatermanagement/docs/2016_sfer_highlights_final?e=4207603/ 33817547 (accessed on 15 March 2016).

26. Florida Fish and Wildlife Conservation Commission. Python Permit Program Frequently Asked Questions. Available online: http://myfwc.com/wildlifehabitats/nonnatives/python/faqs/permit-faqs/ (accessed on 2 May 2016).

27. U.S. Environmental Protection Agency. Americas Wetlands-Our Vital Link between Land and Water. Available online: https://www.csu.edu/cerc/documents/AmericasWetlands.pdf (accessed on 10 November 2015).

28. Center for Urban and Environmental Solutions at Florida Atlantic University. The Economics of the Everglades Watershed and Estuaries. Available online: http://www.drivecms.com/uploads/ riverofgrasscoalition.com/1022369245The \%20Economics\%20of\%20the \%20Everglades $\% 20$ FINAL $\% 20$ REP ORT.pdf (accessed on 10 November 2015).

29. Florida Department of Environmental Protection. Kissimmee River Watershed. Available online: http://www.protectingourwater.org/watersheds/map/kissimmee_river/ (accessed on 2 May 2016).

30. Havens, K.E.; Gawlik, D.E. Lake Okeechobee Conceptual Ecological Model. Wetlands 2005, 25, 908-925. [CrossRef]

31. Byrne, M.J.; Wood, S.M. Concentrations and Loads of Nutrients in the Tributaries of the Lake Okeechobee Watershed, South-Central Florida, Water Years 2004-2008: U.S. Geological Survey Data Series 613. Available online: https://pubs.usgs.gov/ds/613/pdf/USGS_DS-613_Byrne.pdf (accessed on 2 May 2016).

32. Cantillo, A.Y.; O'Connor, T.P.; Lauenstein, G.G. South Florida Environmental Quality. NOAA Technical Memo, NOS ORCA 75. Available online: http://www.aoml.noaa.gov/general/lib/sfeq.pdf (accessed on 27 June 2016).

33. Boyer, J.N.; Fourqurean, J.W.; Jones, R.D. Seasonal and Long-Term Trends in the Water Quality of Florida Bay. Estuaries 1999, 22, 417-430. [CrossRef]

34. Lorenz, J.J. A Review of the Effects of Altered Hydrology and Salinity on Vertebrate Fauna and Their Habitats in Northeastern Florida Bay. Wetlands 2014, 34, 189-200. [CrossRef]

35. Kang, W.-J.; Trefry, J.H. Identifying increased inputs of terrestrial phosphorus to sediments of the southwestern Everglades and Florida Bay. Estuar. Coast. Shelf Sci. 2013, 129, 28-36. [CrossRef]

36. Melesse, A.M.K.; Zhang, K. Modeling Costal Eutrophication at Florida Bay Using Neural Networks. J. Coast. Res. 2008, 24, 190-196. [CrossRef]

37. Woodland, R.J.; Thomson, J.R.; MacNally, R.; Reich, P.; Evrard, V.; Wary, F.Y.; Walker, J.P.; Cook, P.L.M. Nitrogen loads explain primary productivity in estuaries at the ecosystem scale. Limnol. Oceanogr. 2015, 60, 1751-1762. [CrossRef]

38. Izuno, F.T.; Rice, R.W.; Capone, L.T. Best Management Practices to Enable the Coexistence of Agriculture and the Everglades Environment. Hort Sci. 1999, 34, 27-33.

39. Fling, H.E.; Aumen, N.G.; Armentano, T.; Mazzotti, F.J. The Role of Flow in the Everglades Landscape. Soil Water Deparment of University of Florida IFAS Extension Publication CIR 1452. Available online: https://edis.ifas.ufl.edu/pdffiles/UW/UW19900.pdf (accessed on 23 August 2016). 
40. Sklar, F.; McVoy, C.; van Zee, R.; Gawlik, D.; Swift, D.; Park, W.; Fitz, C.; Wu, Y.; Rudnick, D.; Fontaine, T.; et al. Chapter 2-Hydrologic Needs: The Effect of Altered Hydrology on the Everglades. Everglades Interim Report. Available online: http://www.sfwmd.gov/portal/page/portal/pg_grp_sfwmd_sfer/portlet_ prevreport/interimrpt_98/chpt2.pdf (accessed on 23 August 2016).

41. U.S. Geological Survey. Land Subsidence in the United States. Available online: http://pubs.usgs.gov/circ/ circ1182/pdf/circ1182_intro.pdf (accessed on 10 November 2015).

42. Prinos, S.T.; Wacker, M.A.; Cunningham, K.J.; Fitterman, D.V. Origins and Delineation of Saltwater Intrusion in the Biscayne Aquifer and Changes in the Distribution of Saltwater in Miami-Dade County, Florida. U.S. Geological Survey. Available online: http://pubs.usgs.gov/sir/2014/5025/pdf/sir2014-5025.pdf (accessed on 23 August 2016).

43. University of Florida. Mitigating Saltwater Intrustion through Everglades Restoration: A Policy Proposal for the Florida Legislature. Available online: http:/ / www.bobgrahamcenter.ufl.edu/sites/default/files / mitigating_saltwater_intrusion_policy_proposal.pdf (accessed on 23 August 2016).

44. Reddy, K.R.; Newman, S.; Osborne, T.Z.; White, J.R.; Fitz, H.C. Phosphorus Cycling in the Greater Everglades Ecosystem: Legacy Phosphorus Implications for Management and Restoration. Environ. Sci. Technol. 2011, 41, 149-186. [CrossRef]

45. Chebud, Y.; Naja, G.M.; Riveroa, R. Phosphorus Run-off Assessment in a Watershed. J. Environ. Monit. 2011, 13, 66-73. [CrossRef] [PubMed]

46. Daroub, S.H.; Stuck, J.D.; Lang, T.A.; Diaz, O.A. Particulate Phosphorus in the Everglades Agricultural Area: I-Introduction and Sources. Soil Water Department of University of Florida IFAS Extension Publication SL 197. Available online: https:/ / edis.ifas.ufl.edu/pdffiles/SS/SS41000.pdf (accessed on 10 November 2015).

47. Frossard, F.; Brossard, M.; Hedley, M.J.; Metherell, A. Reactions controlling the cycling of P in soils. In Phosphorus in the Global Environment: Transfers, Cycles, and Management; Tiessen, H., Ed.; John Wiley \& Sons: New York, NY, USA, 1995.

48. Diaz, O.A.; Daroub, S.H.; Stuck, J.D.; Clark, M.W.; Lang, T.A.; Reddy, K.R. Sediment Inventory and Phosphorus Fractions for Water Conservation Area Canals in the Everglades. Soil Sci. Soc. Am. J. 2006, 70, 863-871. [CrossRef]

49. Pfeuffer, R.J. Pesticide Surface Water Quality Report November 2015 Sampling Event; South Florida Water Management District: West Palm Beach, FL, USA, 2015.

50. Quinete, N.; Castro, J.; Fernandez, A.; Zamora-Ley, I.M.; Rand, G.M.; Gardinali, P.R. Occurrence and Distribution of Endosulfan in Water, Sediment, and Fish Tissue: An Ecological Assessment of Protected Lands in South Florida. J. Agric. Food Chem. 2013, 61, 11881-11892. [CrossRef] [PubMed]

51. Rand, G.M.; Carriger, J.F.; Gardinali, P.R.; Castro, J. Endosulfan and its metabolite, endosulfan sulfate, in freshwater ecosystems of South Florida: A probabilistic aquatic ecological risk assessment. Ecotoxicology 2010, 19, 879-900. [CrossRef] [PubMed]

52. Fink, L.; Rumbold, D.; Rawlik, P. The Everglades Mercury Problem in the Everglades. In Everglades Interim Report; South Florida Water Management District. Available online: https://my.sfwmd.gov/portal/page/ portal/pg_grp_sfwmd_sfer/portlet_prevreport/interimrpt_98/chpt7.pdf (accessed on 2 May 2016).

53. Gabriel, M.C.; Howard, N.; Osborne, T.Z. Fish Mercury and Surface Sulfate Relationships in the Everglades Protection Area. Environ. Manag. 2014, 53, 583-593. [CrossRef] [PubMed]

54. Florida Department of Environmental Protection. Mercury in Aquatic Ecosystems in Florida. Available online: http:/ /www.dep.state.fl.us/Water/sas/mercury/index.htm (accessed on 2 May 2016).

55. Florida Department of Environmental Protection. Blue-Green Algae. Available online: https://www.dep. state.fl.us/water/bgalgae/faq.htm (accessed on 23 August 2016).

56. Reddy, K.R.; White, J.R.; Wright, A.L.; Chua, T. Influence of phosphorus loading on the microbial processes in the soil and water column of wetlands. In Phosphorus Biogeochemistry of Sub-Tropical Ecosystems; Reddy, K.R., O'Connor, G.A., Schelsk, C.L., Eds.; CRC Press: Boca Raton, FL, USA, 1999; pp. 249-274.

57. Surratt, D.; Aumen, N.G. Factors influencing phosphorus levels delivered to Everglades National Park, Florida, USA. Environ. Manag. 2014, 54, 223-239. [CrossRef] [PubMed]

58. Brown, P.; Wright, A.L. The role of periphyton in the Everglades. Soil Water Department, University of Florida IFAS Extension Publication SL 310, 2009. Available online: https:/ /edis.ifas.ufl.edu/pdffiles/SS/SS52200.pdf (accessed on 10 November 2015). 
59. Zelder, J.B.; Kercher, S. Causes and consequences of invasive plants in wetlands: Opportunities, opportunist, and outcomes. Plant Sci. 2006, 23, 431-452.

60. National Research Council. Progress Toward Restoring the Everglades: The Third Biennial Review-2010; The National Academies Press: Washington, DC, USA, 2011.

61. Delfino, J.J.; Heaney, J.P. Challenges to water resources sustainability in Florida. In Proceedings of the Allocating Water: Economics and the Environment, Universities Council on Water Resources, Portland, OR, USA, 22 July 2004. Available online: http:/ / opensiuc.lib.siu.edu/cgi/viewcontent.cgi?article=1106\& context=ucowrconfs_2004 (accessed on 10 November 2015).

62. Light, A.R. Reducing Nutrient Pollution in the Everglades Agricultural Area through Best Management Practices. Nat. Resour. Environ. 2010, 25, 26-30.

63. Inglett, P.W.; Rivera-Monroy, V.H.; Wozniak, J. Biogeochemistry of Nitrogen Across the Everglades Landscape. Environ. Sci. Technol. 2011, 41, 187-216. [CrossRef]

64. Morgan, K.T.; McCray, J.M.; Rice, R.W.; Gilbert, R.A.; Baucum, L.E. Review of Current Sugarcane Fertilizer Recommendations: A Report from the UF/IFAS Sugarcane Fertilizer Standard Task Force. Soil and Water Department, University of Florida IFAS Extension Publication SL 295. Available online: https:/ /edis.ifas.ufl. edu/ss508 (accessed on 2 May 2016).

65. Schindler, D.W.; Carpenter, S.R.; Chapra, S.C.; Hecky, R.E.; Orihel, D.M. Reducing Phosphorus to Curb Lake Eutrophication is a Success. Environ. Sci. Technol. 2016. [CrossRef] [PubMed]

66. U.S. Environmental Protection Agency, Office of Water. Numeric Nutrient Criteria for the State of Florida: Withdrawing the Federal Actions Factsheet. 4305T, EPA-820-F-14-006. Available online: https:/ /www.epa. gov/sites/production/files/2015-07/documents/factsheet-withdrawl-2014.pdf (accessed on 14 June 2016).

67. Florida Department of Environmental Protection. Numeric Nutrient Standards for Florida Waters. Available online: http://www.dep.state.fl.us/water/wqssp/nutrients/ (accessed on 14 June 2016).

68. Schwartz, R.E.; Chung, D.Y.; Mendoza, T. Nutrients in the Courts: Cooperative Federalism Entangles EPA Actions on Nitrogen and Phosphorus. Environ. Law Rep. 2014, 44, 10163-10172.

69. Houck, O.A. Cooperative Federalism, Nutrients, and the Clean Water Act: Three Cases Revisited. Environ. Law Rep. 2014, 44, 10426-10442.

70. Qian, S.S.; Lavine, M. Setting Standards for Water Quality in the Everglades. Chance 2003, 16, 10-16. [CrossRef]

71. Richardson, C.J.; King, R.S.; Qian, S.S.; Vaithiyanathan, P.; Qualls, R.G.; Stow, C.A. Estimating Ecological Thresholds for Phosphorus in the Everglades. Environ. Sci. Technol. 2007, 41, 8084-8091. [CrossRef] [PubMed]

72. Payne, G.; Bennett, T.; Weaver, K. 2002 Everglades Consolidated Report. Chapter 5: Development of a Numeric Phosphorus Criterion for the Everglades Protection Area. Available online: http://www.sfwmd. gov/portal/page/portal/pg_grp_sfwmd_sfer/portlet_prevreport/2002_ecr/Chapters/Ch5.pdf (accessed on 15 June 2016).

73. Florida Department of Environmental Protection. Numeric Interpretations of Narrative Nutrient Criteria. Rule: 62-302.531, F.A.C. Available online: https://www.flrules.org/gateway/ruleno.asp?id=62-302.531 (accessed on 15 June 2016).

74. Florida Deparment of Environmental Protection. Estuary-Specific Numeric Interpretations of the Narrative Nutrient Criterion. Rule: 62-302.532, F.A.C. Available online: https:/ /www.flrules.org/gateway/RuleNo. asp?title=SURFACE\%20WATER\%20QUALITY\%20STANDARDS\&ID=62-302.532 (accessed on 15 June 2016).

75. Water Resources Development Act. Federal Legislation for 2000. Washington, DC, USA. Available online: https:/ / www.fws.gov/habitatconservation/omnibus/wrda2000.pdf (accessed on 10 November 2015).

76. South Florida Water Management District. Quick Facts on: Restoration Strategies for Clean Water for the Everglades. Available online: http:/ / www.sfwmd.gov/portal/pls/portal/docs/17588004.PDF (accessed on 15 March 2016).

77. U.S. Army Corps of Engineers, Jacksonville District. Comprehensive Everglades Restoration Plan (CERP) - Water Flow Maps of the Everglades: Past, Present and Future. Available online: http://141. 232.10.32/education/presentation_materials.aspx (accessed on 20 November 2015).

78. Entry, J.A. The impact of stormwater treatment and best management practices on nutrient concentration in the Florida Everglades. Water Air Soil Pollut. 2014, 225, 1758. [CrossRef]

79. Stone, J.A.; Legg, D.E. Agriculture and the Everglades. J. Soil Water Conserv. 1992, 47, 207-215. 
80. South Florida Water Management District. Below the Surface-An in-depth look at Everglades Stormwater Treatment Areas. Available online: http://www.sfwmd.gov/portal/page/portal/xrepository/sfwmd_ repository_pdf/bts_sta.pdf (accessed on 15 March 2016).

81. Kadlec, R.H.; Wallace, S.D. Treatment Wetlands, 2nd ed.; CRC Press, Taylor \& Francis Group: Boca Raton, FL, USA, 2009.

82. Entry, J.A.; Gottlieb, A. The impact of stormwater treatment areas and agricultural best management practices on water quality in the Everglades Protection Area. Environ. Monit. Assess. 2014, 186, 1023-1037. [CrossRef] [PubMed]

83. Pietro, K. Synopsis of the Everglades Stormwater Treatment Areas, Water Year 1996-2012. South Florida Water Management District Technical Publication ASB-WQTT-12-001. Available online: http://www. wwwalker.net/ever/stas/pdfs/references/STA_Synopsis_1996-2012_ASB-WQTT-12-001.pdf (accessed on 10 November 2015).

84. Leeds, J. South Florida Environmental Report. South Florida Water Management District; Volume I, p. 5B-2. Available online: http://www.sfwmd.gov/portal/page/portal/pg_grp_sfwmd_sfer/portlet_prevreport/ 2016_sfer_final/v1/chapters/v1_ch5b.pdf (accessed on 15 March 2016).

85. Committee on Independent Scientific Review of Everglades Restoration Progress; Water Science and Technology Board, Board on Environmental Studies and Toxicology; Division on Earth and Life Studies, and National Research Council. Progress toward Restoring the Everglades—The Fifth Biennial Review-2014; The National Academies Press: Washington, DC, USA, 2014.

86. Walton, T.L., Jr. Projected sea-level rise in Florida. Ocean Eng. 2007, 34, 1832-1840. [CrossRef]

87. State of Florida Office of the Governor. Executive Order Number 16-155. Available online: http:/ / www.flgov.com/2016/06/29/gov-scott-declares-state-of-emergency-in-st-lucie-and-martincounties-following-algal-blooms / (accessed on 10 July 2016).

88. The George Barley Water Prize. Available online: http://www.barleyprize.com/ (accessed on 15 June 2016).

89. European Sustainable Phosphorus Platform. Available online: http://phosphorusplatform.eu/ (accessed on 8 May 2016).

90. Arizona State University. Sustainable Phosphorus Initiative. Available online: https://sustainablep.asu.edu/ (accessed on 8 May 2016).

91. Douglas, M.S.; Fink, R.; Fitzgerald Rivers of America Collection (Library of Congress). The Everglades: River of Grass; Rinehart: New York, NY, USA, 1947. 